\title{
HECS System Changes: Impact on Students
}

\section{Gillian Beer and Bruce Chapman}

$\mathrm{I}$ n early 2002 the new Minister for Education, Science and Training, Brendan Nelson, announced a wide-ranging reform agenda with respect to the funding (and other areas) of Australian higher education. Over the ensuing months the Government released a number of discussion papers, in a process referred to as Crossroads, and initiated and promoted a series of consultations with stakeholders and others covering the essential issues.

The process led to potentially far-reaching policy changes with respect to the financial operation of Australian universities, announced in the 2003-2004 Commonwealth Budget, and passed by the Parliament in modified form at the end of 2003 (to take effect from 2005). An important part of the reforms concerns the nature and extension of the operation of the Higher Education Contribution Scheme (HECS), the income related arrangement for the payment of student charges introduced in 1989.

This paper addresses several questions. One, what is likely to be the true financial cost for different types of students and graduates subject to increases of 25 per cent in HECS charges (the new HECS-HELP arrangements), given that the first income threshold of repayment is to be increased substantially? Two, what is likely to be the true financial cost to different types of students and graduates of so-called 'full-fees', covered by an income related loan known as FEE-HELP? And three, what are the potential consequences for effective student charges of capping loans at $\$ 50,000$, meaning that some students will have to face the unpalatable requirement of paying a proportion of the charges up-front?

It is important to note that it is not possible to predict from this type of analysis the absolute numbers of students who will face higher, lower or unchanged effective HECS debts from the 2005 reforms. The reason is that there are no available data on the likely distributions of the future incomes of students and the number of graduates in the income categories modelled. We seek instead to illustrate the consequences for students and graduates with typical hypothetical debts and future incomes.

A brief analysis of the benefits of income related loan arrangements, and a description of the changes to HECS to be implemented in 2005 follows. Subsequent sections, in turn, explain the methodology used to analyse the impact of changes on students, present the results under various scenarios for HECSHELP students, and describe the results for those paying full fees under different

Gillian Beer is a Principal Research Fellow at the National Centre for Economic and Social Modelling, University of Canberra, and Bruce Chapman is the Director of the Centre for Economic Policy Research at The Australian National University. 
scenarios of FEE-HELP. These sections are followed by a commentary on the HECS-HELP and FEE-HELP systems and some conclusions.

\section{HECS-HELP and FEE-HELP}

The background to income related charges for higher education

Australia introduced the world's first nationally operated income related charge for higher education in 1989 (the background to the introduction of HECS is examined in Edwards, 2001; and Chapman and Ryan, 2002). At the time the Labor government was intent on students paying for a proportion of the costs of their higher education, for several reasons. One was that there was evidence of emerging and considerable unmet demand for university places, but the government was not prepared to expand the system through the provision of additional taxpayer resources. A second reason was the view, held strongly by some in Federal Cabinet at the time, that a so-called 'free' higher education was very regressive economic policy. The essential argument is that if higher education is financed from general tax revenue, it follows that the majority of these resources are provided by average taxpayers with much lower lifetime incomes than those received by graduates. This argument is documented and supported in Chapman (1997).

Given the policy commitment to a charge, the next important issue related to the form in which it should be paid. In an international context there are many possibilities such as: up-front fees with means-tested scholarships; and up-front fees with means-tested access to government guaranteed commercial bank loans. For a variety of reasons examined in Chapman and Ryan (2002) these approaches have significant weaknesses and are unlikely to maximise the chances of the participation of relatively disadvantaged students. Income related loans, on the other hand, seemed to provide the opportunity of minimising the problems associated with other approaches. It was these advantages that lead to the design, development and implementation of HECS.

Income related loans were not invented in Australia, and can be traced in the economics literature to at least as far back as Friedman (1955). However, a workable income related loan scheme was not in practice before HECS. At the time of the debate surrounding the introduction of HECS, public concerns were expressed suggesting that the scheme would discourage the enrolment of disadvantaged groups. However, there is now a considerable body of research suggesting that there have been no discernible effects on university enrolments of relatively poor students from either the introduction of, or changes to, HECS (see, for example, Andrews, 1999; and Chapman and Ryan, 2002).

At the same time as the government introduced HECS for undergraduates, it allowed universities to charge up-front fees for some postgraduate students, and the numbers involved grew consistently over the 1990s. The up-front form of Australian postgraduate charges sat uncomfortably alongside HECS, and some commentators argued strongly for the application of income related loans to both 
postgraduates and for TAFE students. Productive changes came in the form of the Postgraduate Education Loan Scheme (PELS), which provided postgraduate students paying up-front fees access to a HECS-type loan. An analysis of PELS is provided in Chapman and Salvage (2001). From 2005, PELS will become part of FEE-HELP, described below.

\section{HECS-HELP}

Under the new legislation, from 2005 universities will be able to set their own prices for all HECS students, up to a ceiling. With the exception of nursing and education (where no real changes will be allowed) the ceilings will be 25 per cent higher than the projected 'standard' HECS levels in that year. These changes to the basic HECS arrangements are known as 'HECS-HELP'.

The other important feature of HECS-HELP is that the repayment parameters for the repayment of the debt will be changed significantly in 2005. Most importantly, the first income threshold of repayment has been raised considerably, from its current level of about \$26,500 per annum to just over \$36,000 (and there are some additional steps, including higher repayment rates for incomes above $\$ 50,000$ ). Current and 2005 repayment rates are shown in Table 1, with these changes constituting a very critical factor concerning the likely impact of the policy reforms.

Changes to the HECS repayment rules illustrated in Table 1 suggest that there are two forces at work with respect to the present values of future HECS obligations. The first, and by far the most important, is that graduates with annual incomes between about $\$ 27,000$ and $\$ 36,000$ per annum in 2005 will repay none of their debt in that particular year, compared to between about $\$ 750$ and $\$ 1,400$ per year under the current parameters. This change affects significantly the results of our simulations reported below because it decreases the present value of 2005 higher education debts, and very significantly so for some students.

The second set of changes takes the form of higher HECS repayment rates above just over $\$ 50,000$ per annum. Currently, the highest rate is 6 per cent of taxable incomes but after 2005 this will be increased, reaching 8 per cent at $\$ 67,000$ per annum. Our calculations reveal that this increase will have a minor effect on the present value of new debt for graduates expecting to earn relatively high future incomes. 
Table 1: Current and New HECS Repayment Rates and Thresholds in 2005

\begin{tabular}{lclc}
\hline $\begin{array}{c}\text { 2003-04 HECS repayment schedule } \\
\text { inflated to 2005-06 levels }\end{array}$ & 2005-06 HECS repayment schedule \\
Taxable income & $\begin{array}{c}\text { Per cent } \\
\text { applied to } \\
\text { repayment }\end{array}$ & \multicolumn{1}{c}{ Taxable Income } & $\begin{array}{c}\text { Per cent } \\
\text { applied to } \\
\text { repayment }\end{array}$ \\
\hline Below $\$ 26,363$ & Nil & Below $\$ 36,184$ & Nil \\
$\$ 26,363-\$ 27,427$ & 3.0 & $\$ 36,184-\$ 40,306$ & 4.0 \\
$\$ 27,428-\$ 29,958$ & 3.5 & $\$ 40,307-\$ 44,427$ & 4.5 \\
$\$ 29,959-\$ 34,751$ & 4.0 & $\$ 44,427-\$ 46,762$ & 5.0 \\
$\$ 34,752-\$ 41,942$ & 4.5 & $\$ 46,763-\$ 50,266$ & 5.5 \\
$\$ 41,943-\$ 44,145$ & 5.0 & $\$ 50,267-\$ 54,439$ & 6.0 \\
$\$ 44,146-\$ 47,454$ & 5.5 & $\$ 54,440-\$ 57,304$ & 6.5 \\
$\$ 47,455$ and above & 6.0 & $\$ 57,305-\$ 63,062$ & 7.0 \\
& & $\$ 63,063-\$ 67,199$ & 7.5 \\
& & $\$ 67,200$ and above & 8.0 \\
\hline
\end{tabular}

Source: 2003-04 HECS repayment schedule from HECS Information 2004, Department of Education, Science and Training, 2003, http://www.hecs.gov.au/hecs.htm.

\section{FEE-HELP}

The second significant change to student funding is known as 'FEE-HELP', and represents an extension of Australia's income related loan scheme. Under FEEHELP, HECS-type loans will be made available to cover full-fee paying domestic and postgraduate courses, with repayments to be made according to the new repayment parameters. Universities will be able to fill up to 35 per cent of domestic places with full fee paying students.

Arguably FEE-HELP had its origins in the extensive reforms to funding arrangements introduced by the Coalition in 1997. As part of this policy package the government allowed universities, for the first time, to charge domestic students full fees. Only a very small number of students took up this opportunity, for reasons undoubtedly associated with the need for students to find the financial resources to pay up-front, which would have required access to as much as $\$ 16,000$ per full time year.

However, from 2005 there will be no need for a student accepted under full fee paying arrangements to have up-front financial resources because such an enrolment can be accessed with the (substantial) help of a HECS-type loan. As a 
result of this (and other changes) Phillips and Chapman (2003) suggest that the offer of an income related loan facility for full fee paying students will result eventually in a significant take-up of this option.

A critical issue for an analysis of the potential effects of FEE-HELP is that the total level of loans will be capped at $\$ 50,000$ per student. This introduces the real possibility that some students, denied access to further loans, will have to pay up-front fees to complete their higher education, a prospect modelled with the results being reported below. Some (major) concerns with the conceptual basis of FEE-HELP are discussed later.

\section{Methodology}

\section{Conceptual background on the effects of HECS-HELP and FEE-HELP}

There are two opposing forces at work with respect to the effects of changes to the system on the true charges faced by students. The obvious likely change, and the one that has had prominent media and political attention, is that the new arrangements have the very real potential to result in higher levels of HECS debts for a large number of students. There is little doubt that this will happen, in part because the government's indexation rule with respect to recurrent grants means that most institutions have experienced on-going effective real cuts in public sector support since 1995. Phillips and Chapman (2003) document the importance of this issue and explain why shortfalls in indexation will strongly encourage universities to increase charges in 2005 and beyond.

On the other hand, there is a critical aspect of the reforms with significant potential to diminish the financial impact for students of increases in the apparent levels of debt. It is that the repayment parameters for HECS will generally be much more generous after 2005. Most importantly, the first income threshold of HECS repayment has been increased to over $\$ 36,000$ per annum, or by nearly $\$ 10,000$.

The large increase in the first income threshold of repayment after 2005 is a fundamental issue with respect to an assessment of the possible impact of both HECS-HELP and FEE-HELP for students. It is also an issue not generally well understood by those not well versed in financial accounting. Because it is an essential aspect of our exercises, it is worth taking space here to explain its importance.

The critical policy point is that once incurred, HECS debts have a real interest rate of zero. The importance of this relates to what economists call "discounting". Discounting refers to the notion that a financial obligation of a given real amount that has to be met today is more of a burden than if the same sum has to be paid in, say, one year's time. To illustrate this, imagine that you have to repay a loan of $\$ 100$, but you have the choice to pay it today or in one year's time. The reason that most would choose to repay later is that if the debt is not paid now, the money has value over the ensuing year. 
The critical point is that the HECS interest rate subsidy means that a financial advantage accrues that increases with the length of time it takes a graduate to repay a given level of debt. That is, the longer is the expected period of nonrepayment of HECS, the lower is the true cost and significance of the debt at the point that the obligation is incurred. For this reason economists focus on what is known as the present value of a debt, since this calculation takes into account the value of discounting in assessments of the real consequences of debt.

The above explanation of discounting suggests strongly that it is the present value of a HECS debt which will affect higher education students' enrolment behaviour. The importance of this for our exercises is that the new arrangements combining higher HECS with more generous repayments can increase or decrease the present values of higher education debts, meaning that the overall effects cannot be predicted a priori. But, because the exercises reported below are comparisons of changes in the present value of student charges, we are able to model the true financial effects of nominal HECS increases juxtaposed with the more generous 2005 repayment rules.

\section{The modelling approach}

In order to analyse the effects of changes to HECS on the new prices faced by students it is necessary to define hypothetical student experiences. We begin with the assumption that in all cases the individual begins full time higher education at age 18 and studies full-time for a period of four years, regardless of the course taken. It is acknowledged that, in general, courses in the lower HECS bands are of shorter duration. However, we are confident that this simplification has no significant consequences for the overall results.

After graduation, individuals are assumed to start full time work (at age 22). For each hypothetical student considered, the approach imposes a 'typical' lifetime labour force profile (detailed below). On the basis of assumed labour force and earnings profiles, taxable incomes are calculated for each year from age 18. From these taxable incomes HECS repayments are calculated using the parameters from Table 1. Comparative HECS debts are calculated on the basis of assumed course type using the projected standard 2005-06 HECS charges. For a middle (that is, Band 2) HECS band course, the standard HECS charge in 2005-06 is $\$ 5,400$ per annum. For simplicity, the body of what follows considers only the effects on students assumed to be undertaking a course in the middle HECS band, since the essence of the results are similar for other HECS bands.

The model is run a number of times for each hypothetical individual, in two stages. First, present values of HECS repayments are estimated under the current system (that is, using the projected 2005-06 standard HECS charges and the current repayment thresholds inflated to 2005-06 dollars). These are then compared to present values calculated for a range of 2005 hypothetical scenarios: a 25 per cent increase in the charge; a FEE-HELP debt of \$50,000; and a FEEHELP debt of $\$ 50,000$ with an up-front fee. In all cases we use a discount rate of five per cent per annum to calculate the present value. This is a rate 
conventionally used in empirical applications of this kind, although others could have been employed. It is unlikely that the essential results would be changed importantly if different discount rates had been employed.

A total of nine hypothetical cases are modelled. Each case is assumed to have done a course in the middle HECS band. They are as follows:

1. Male, high-income graduate;

2. Male, middle-income graduate;

3. Male, low-income graduate;

4. Female with no children, high-income graduate;

5. Female with no children, middle-income graduate;

6. Female with no children, low-income graduate;

7. Female with two children, high-income graduate;

8. Female with two children, middle-income graduate;

9. Female with two children, low-income graduate.

\section{Assumed lifetime labour force and earnings profiles}

Typical lifetime labour force profiles are assumed for each hypothetical case, with the profiles being constructed on the basis of gender and education. The profiles are used to derive an individual's projected wage and salary income in each year over their lives.

In general, individuals without children are assumed to work full-time for most of their working lives. For women with children, it is quite different. After they complete university at the age of 22, they are assumed to work full time until they reach 30 years of age, when they leave the labour force to rear children. They re-enter the labour force part-time after four years and then resume full-time employment when they reach 40 years of age.

The lifetime earnings profiles have been derived from the Australian Bureau of Statistics (ABS) 1996-97 and 1997-98 Surveys of Income and Housing Costs (SIHC). The two different survey years were used to ensure that sample sizes are sufficiently large.

Graduates were allocated into high, medium and low earning categories as follows. The profiles for high-income males and females are calculated as the average wage and salary income for the highest 33 per cent of full-time male and full-time female undergraduate degree holders respectively. The profile for middle-income earners is calculated as the average wage and salary income for the middle 33 per cent of full-time male and full-time female undergraduate degree holders respectively. Accordingly, the profile for low-income earners is taken as the average wage and salary income for the lowest 33 per cent of full-time male and full-time female undergraduate degree holders respectively.

Overall, therefore, the construction of the lifetime profiles is undertaken separately by gender, with no differentiation in the estimation from the SIHC data by marital status. There is also no differentiation on the basis of the university at which the individual undertook their undergraduate degree. 
The profiles have been estimated for full-time workers only. In the calculations for the hypothetical cases, wage and salary income for any part-time work is assumed to be 30 per cent of full-time earnings for males and 45 per cent of full-time earnings for females. These ratios are set on the basis of a comparison of part-time and full-time earnings as revealed by the 1994-95 ABS SIHC.

The incomes derived from the two SIHCs have been inflated to 2005 levels on the basis of expected changes in average weekly earnings. We have assumed an increase of 7.5 per cent in nominal earnings between 2003 and 2005. The final earnings profiles used in this study are shown in Figures 1-3.

An important point from the profiles is that there are very large differences both within and between groups. The earnings of high-income male graduates working full time, for example, peak at around $\$ 120,000$ per annum, but the peak for low-income female graduates working full time is less than $\$ 40,000$ per annum. These differences suggest a strong potential for the calculations to reveal very large contrasts by group in the present value calculations related to HECS changes.

Figure 1: Derived Lifetime Earnings Profiles for Low, Middle and High-income Graduate Males

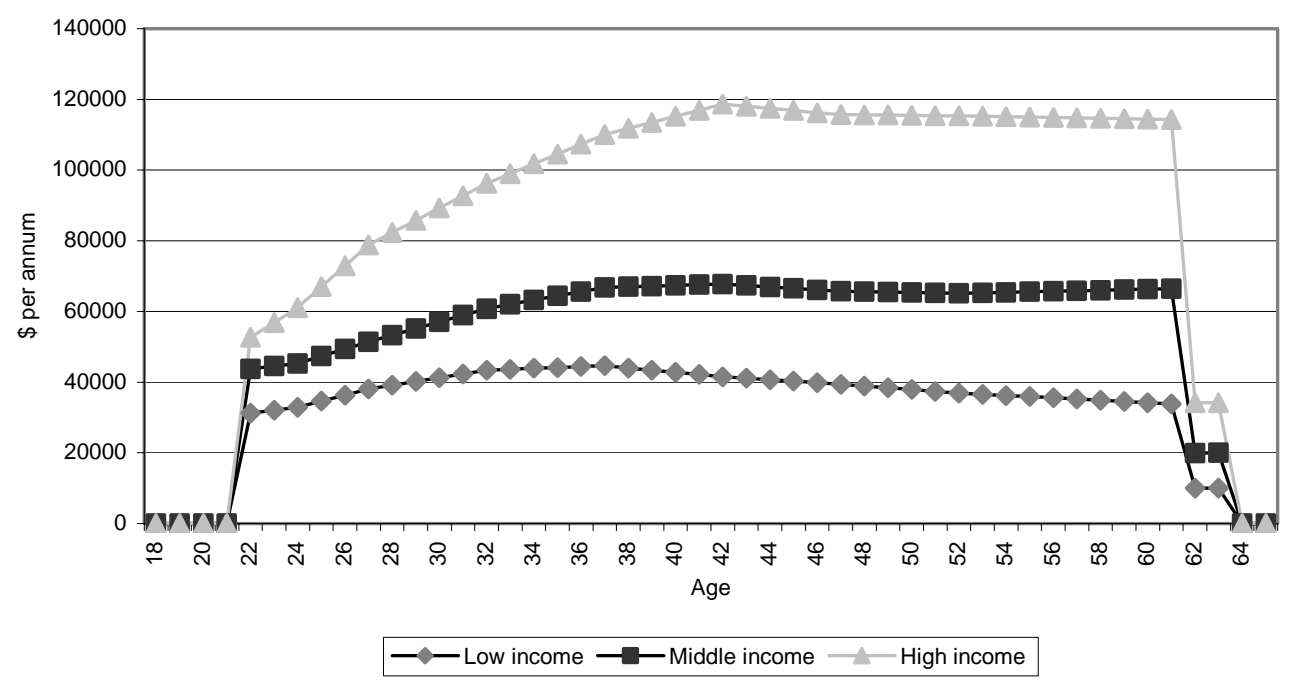

Data source: ABS, 1996-97 and 1997-98 Survey of Income and Housing Costs. 
Figure 2: Derived lifetime Earnings Profiles for Low, Middle and High-income Graduate Females without Children

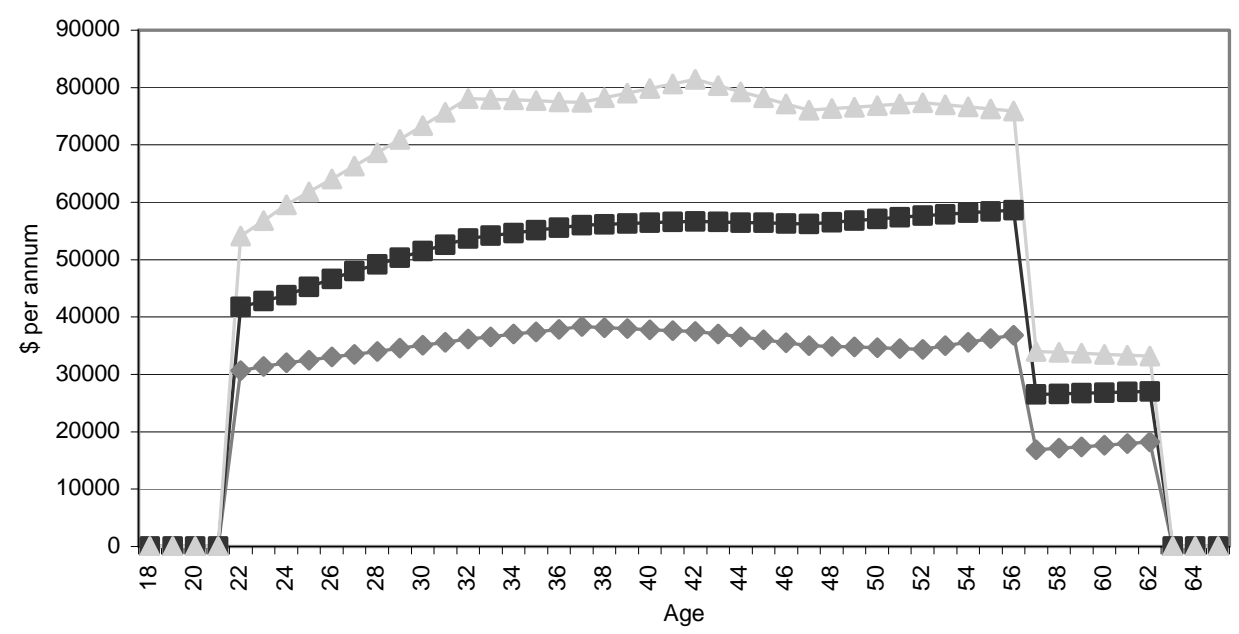

$\longrightarrow$ Low income $\longrightarrow$ Middle income $\longrightarrow$ High income

Data source: ABS, 1996-97 and 1997-98 Survey of Income and Housing Costs.

Figure 3: Derived Lifetime Earnings Profiles for Low, Middle and High-income Graduate Females with Two Children

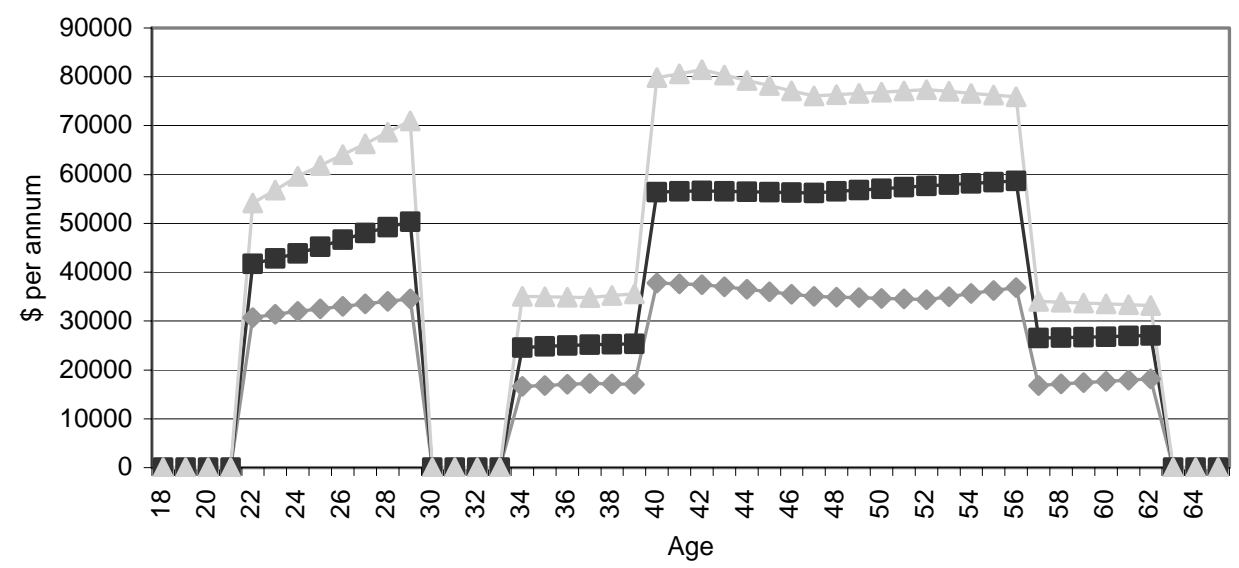

$\multimap-$ Low income $\neg-$ Middle income $\longrightarrow$ High income

Data source: ABS, 1996-97 and 1997-98 Survey of Income and Housing Costs. 


\section{Results for HECS-HELP Students}

In this section results are presented for hypothetical HECS-HELP students/graduates. The approach is to calculate the present value of HECS repayments for the current arrangements (the base case) and to compare these with 25 per cent increases in the debt under HECS-HELP. Table 2 shows the results.

Table 2: Present Value of HECS Repayments for Hypothetical HECS-HELP Individuals Paying Middle HECS under Alternative Scenarios

\begin{tabular}{lccc}
\hline & Males & $\begin{array}{c}\text { Females } \\
\text { no children }\end{array}$ & $\begin{array}{c}\text { Females } \\
\text { 2 children }\end{array}$ \\
\hline $\begin{array}{l}\text { Low-income } \\
\quad \text { Base system } \\
\text { 2005-06 system with 25\% } \\
\text { surcharge }\end{array}$ & 12,600 & 12,000 & 9,900 \\
$\begin{array}{l}\text { Middle-income } \\
\quad \text { Base system }\end{array}$ & 12,000 & 4,100 & 1,400 \\
$\quad \begin{array}{l}\text { 2005-06 system with 25\% } \\
\text { surcharge }\end{array}$ & 14,200 & 13,900 & 13,300 \\
$\begin{array}{l}\text { High-income } \\
\quad \text { Base system }\end{array}$ & 16,800 & 16,400 & 14,500 \\
$\quad \begin{array}{l}\text { 2005-06 system with 25\% } \\
\text { surcharge }\end{array}$ & 18,700 & 18,600 & 18,600 \\
\hline
\end{tabular}

The results from the table suggest very large differences in the present value calculations of HECS arrangements. For example, in the base case, low-income females with children face present values of their debt of $\$ 9,900$, while highincome males face $\$ 15,200$. Moving to the new system, these differences increase significantly, with members of the former group now facing only $\$ 1,400$ (since most of the debt will remain unpaid) compared to $\$ 18,700$ for the latter.

The very striking result is that for low-income graduates the new system, even with a 25 per cent increase in HECS, results in lower present values of students' debts. However, between groups the changes are very different. For example, for males there is close to no change, but for females without and with children the decreases are in the order of 66 and 86 per cent respectively. This illustrates the very considerable benefit of the increase in the first threshold of repayment for low-income females. 
The data suggest that the new system will increase the present value of the debt for all three middle-income groups but by less than the 25 per cent apparent increase in the charge. For males and females without children the increase is about 18 per cent, but for females with children the increase is around 9 per cent.

The results illustrate that the new system impacts much more adversely on the present values of high-income graduates. Males, for example, will pay 23 per cent more, and even females with children will face present values of the debt which are 23 per cent higher. The basic reason that the high-income graduates face significantly higher increases in the present values of their debts is that members of these groups receive none of the subsidy benefits associated with the large increase in the first income threshold of repayment of HECS.

Several other results are worth explaining. One is that the lower present value for women with children generally is a result of members of this group taking time out of the labour force at age 30 to rear children. In the case of those in the low and middle-income bands, they will not have fully repaid their HECS debt before this time. Once they start having children they have around 10 years in which they make no HECS repayments because they are either not working for pay or are working part-time and thus earning less than the threshold. This results in very large subsidies going to this group.

Second, the higher present values of debt for males stems from the fact that males have higher wage and salary incomes than females of the same age (as shown in Figures 1-3). This in turn means that their taxable income is higher and thus, they repay their HECS debts more quickly than females. The greater are repayments at earlier ages the lower is the effective subsidy for males and thus, the higher are the present values of their debts.

The essential messages remain the same under a 25 per cent increase in the HECS charge for graduates who undertake a course in the low or high HECS bands.

\section{Results for FEE-HELP Students}

In this section results are presented for FEE-HELP students. We have simulated a debt of $\$ 12,500$ per year for a four-year duration of study, under the assumption that students admitted under FEE-HELP are unable to access a HECS-HELP place at any stage of their undergraduate program of study. FEE-HELP takes the form of there being a surcharge of 25 per cent on top of the fee level, so the $\$ 12,500$ borrowed per year is equivalent to an annual charge of $\$ 10,000$. The figures have been chosen to reflect the maximum allowed total debt of $\$ 50,000$.

The student/graduate income hypothetical cases we have used are the same as those for HECS-HELP scenarios, but obviously without the distinction between the HECS bands. Thus, again there are a total of nine cases - males, females without children and females with two children, on low, middle and high-incomes.

There are two sets of simulations, with the first being explained above. The second allows insights into the possible importance of HECS debts being capped at a level of $\$ 50,000$ per student. An issue in this circumstance is that some 
students might reach the loan cap before they have completed their education, and will thus need to pay the remaining charge up-front (if, of course, they are able to access the required finances). To simplify the analysis we assume for this simulation that the student is in a course charging $\$ 13,333$ per year for three years, which puts the student at the loan cap after three years and means that they will need to pay for the final year up-front. The results of these simulations are shown in Table 3. For comparative purposes the table also shows the present value of debt repayments for HECS-HELP students in the middle HECS band.

Table 3: Present Value of HECS Repayments for Hypothetical FEEHELP Individuals under Different Scenarios

\begin{tabular}{|c|c|c|c|}
\hline & Males & $\begin{array}{l}\text { Females } \\
\text { no children }\end{array}$ & $\begin{array}{l}\text { Females } \\
2 \text { children }\end{array}$ \\
\hline \multicolumn{4}{|l|}{ Low-income } \\
\hline $\begin{array}{l}\text { HECS-HELP individual in the } \\
\text { middle HECS band (base system) }\end{array}$ & 12,600 & 12,000 & 9,900 \\
\hline $\begin{array}{l}\text { Full fee paying with a total debt of } \\
\$ 50,000\end{array}$ & 16,300 & 4,100 & 1,400 \\
\hline $\begin{array}{l}\text { Full fee paying with a total debt of } \\
\$ 50,000 \text { plus an up front payment } \\
\text { of } \$ 13,333 \text { in fourth year of study }\end{array}$ & 27,200 & 15,100 & 12,300 \\
\hline \multicolumn{4}{|l|}{ Middle-income } \\
\hline $\begin{array}{l}\text { HECS-HELP individual in the } \\
\text { middle HECS band (base system) }\end{array}$ & 14,200 & 13,900 & 13,300 \\
\hline $\begin{array}{l}\text { Full fee paying with a total debt of } \\
\$ 50,000\end{array}$ & 26,600 & 25,200 & 20,200 \\
\hline $\begin{array}{l}\text { Full fee paying with a total debt of } \\
\$ 50,000 \text { plus an up front payment } \\
\text { of } \$ 13,333 \text { in fourth year of study }\end{array}$ & 37,500 & 36,200 & 31,100 \\
\hline \multicolumn{4}{|l|}{ High-income } \\
\hline $\begin{array}{l}\text { HECS-HELP individual in the } \\
\text { middle HECS band (base system) }\end{array}$ & 15,200 & 15,100 & 15,100 \\
\hline $\begin{array}{l}\text { Full fee paying with a total debt of } \\
\$ 50,000\end{array}$ & 31,100 & 30,400 & 27,400 \\
\hline $\begin{array}{l}\text { Full fee paying with a total debt of } \\
\$ 50,000 \text { plus an up front payment } \\
\text { of } \$ 13,333 \text { in fourth year of study }\end{array}$ & 42,100 & 41,400 & 38,400 \\
\hline
\end{tabular}


The data from the table show some surprising results. One is that even if low-income females incur a debt of $\$ 50,000$ they will pay close to nothing (that is, $\$ 1,400$ ), and even females with no children will face a present value of a debt of only $\$ 4,100$. As incomes increase, so too does the present value of the debt, and for high-income males a $\$ 50,000$ debt on paper is associated with a present value of over $\$ 30,000$, which is around double the base case of HECS-HELP for a middle level charge. The most striking result however, relates to the requirement of paying an up-front fee on top of the debt, and this is stressed in what follows.

The data for low-income FEE-HELP students are of great interest. They show that low-income individuals face small (or zero) increases only from having a $\$ 50,000$ debt (compared to HECS-HELP) but that there are extremely high present value increases once an up-front payment is required. The results are particularly striking for females, with just one year's up-front payment meaning an increase in the present value of the debt of over 300 per cent (from about $\$ 4,000$ to over $\$ 15,000$ ) for females with no children and about a factor of 8 (from $\$ 1,400$ to $\$ 12,300$ ) for females with two children. These are extraordinary results illustrating the great financial importance of HECS-type loans for those expecting to earn low-incomes.

The results for middle-income students suggest that the present value of the $\$ 50,000$ debt is approximately doubled from the HECS-HELP arrangement for middle-income graduates. As with low-income graduates, the effects of the addition of the up-front payment are striking, although less so. The up-front charge adds at least 40 per cent to the present value of the charge, with the relative increase for females with children being the highest, from about $\$ 20,000$ to over $\$ 30,000$.

The results for high-income students suggest that FEE-HELP with a $\$ 50,000$ debt will have similar proportionate effects on the present value of the debts of high-income earners as is the case for middle-income graduates. However, while the up-front payment considerably increases the extent of the charge burden for high-income graduates, in proportionate terms the effects are far lower than for less advantaged graduates. Overall, the up-front payment scenario illustrates that the capping of the loan has the strong potential to burden the lowest earning graduates and can be seen to be regressive in a lifetime income sense.

\section{A Commentary on HECS-HELP and FEE-HELP}

\section{Price flexibility in theory}

There seem to be two important motivations for the proposed introduction of HECS-HELP. One is apparently the recognition that in the early 2000s there are significant financial pressures on Australian universities, and that some price flexibility would be likely to increase their revenue. Phillips and Chapman (2003) argue that overall there is little doubt that the new arrangements will mean higher average contributions from HECS students; in a sense the government will be 
transferring the problem associated with indexation shortfalls away from taxpayers to students.

The second likely reason for increased higher education pricing autonomy is the recognition that Australia is now in a situation whereby universities supply services for a large and diversified market. Higher education is no longer elite and small, and there might increasingly be opportunities for specialisation in terms of both subject matter and the targeting of particular consumers.

In this context, issues of resource allocation promote the case for allowing universities to offer services and prices reflecting (to a limited extent) their circumstances and goals. The argument promoted by Norton (2002) and others is that this would allow more choice for both providers and students, and thus has the potential to improve service delivery.

In summary it would seem that, apart from the implications for the prices faced by students, HECS-HELP is likely to have two institutional effects. One is that universities would have more revenue, which would be supplied through higher imposts on students. Whether or not this is desirable in terms of economic theory depends on the subjective valuation given to the value of externalities. However, it would seem to be the case that the potential for further large changes in this context is limited.

Second, so long as most of the additional revenue is delivered directly to the university departments (this is in fact how HECS-HELP is proposed to operate) there is some potential to promote economically propitious outcomes, such as relative changes in academic salaries to more accurately reflect outside opportunities.

But if universities are to have some discretion over prices, several questions arise. The most important of these concerns the extent to which there should be price regulation. That is, a critical issue concerns the extent to which universities should be free to set prices.

Clearly, given the price ceiling that has been set of 25 per cent above standard HECS, this policy change has been motivated by the view that there should not be unlimited price discretion for the majority of undergraduate students. There are very solid grounds to support such a position, now considered.

The reasons to be concerned about unfettered price competition between Australian universities are as follows. First, the extent to which institutions will be able to benefit from price discretion will be a result of their location and history. For example, the Universities of Sydney, Queensland, Western Australia, Adelaide and Melbourne are located in prime areas of their respective cities, and this gives them a significant commercial advantage. The fact that universities do not pay rent means that the playing field is not level.

Second, an important part of universities' relative standing is the result of many years of public sector subsidy. Reputations have been built from these subsidies, implying that there might be important rents accruing to some universities from unfettered price competition. In turn this suggests that the alleged benefits of competition could be undermined without close attention to these issues of both geography and history. 
These first two reasons suggest that allowing completely free market principles in the pricing of higher education services in Australia, such as with respect to FEE-HELP, is currently inappropriate, and will likely lead to significant economic rents accruing to well-placed and highly reputable institutions. These concerns could be resolved in part if universities were to compensate the public sector for these advantages, but there seems to be little contemporary discussion of this issue.

There is an additional reason for not allowing unfettered pricing flexibility, and it relates to the charge burdens on students. It is difficult to believe that the current HECS levels are markedly below what they should be. In some cases, Law for example, it is very likely that students are currently paying almost as much as the teaching costs involved. Full price discretion would suggest that such examples are likely to become commonplace. This rests uneasily with the economic rationale for public sector additional financial support, which suggests that activities associated with spill-over social benefits should be subsidised by taxpayers; in other words, that students should pay less than the full costs of the activity.

\section{Concerns with FEE-HELP}

FEE-HELP makes a HECS-type loan available to full-fee paying students and this constitutes an improvement over the current poor arrangements introduced in 1997 in which universities are able to charge full fees for 25 per cent of the course quota. But there are several significant problems with FEE-HELP. The first, outlined above, is that there is not a case to allow universities full price discretion. Particularly when seen in the context of restrictions in the supply of places, this will deliver unreasonable non-market rents to institutions and will not foster competition.

These arguments reinforce the case for the Government capping fees. Indeed, the force of this point seems to underlie the Government's decision to set the limit of 25 per cent on the extent to which universities are able to increase HECS-HELP charges. It is notable that the same understandings have not apparently influenced the policy approach to so-called 'full-fee paying' students.

There are several possible alternatives involving price capping. Perhaps the most persuasive has been argued by Phillips, in which the cap on fees could be set somewhat higher than the maximum HECS-HELP. Phillips' proposal thus suggests that there should be no HECS charge differences between domestic students. In his arrangement there is the major equity plus of the removal of the price distinction between full-fee and HECS-liable students, since all domestic students in the same course would pay the same charge. Not only would this simpler alternative eliminate the equity concerns about having two classes of domestic students, it would also remove the need for measures to constrain and penalise over-enrolment (Phillips and Chapman, 2003).

The second major issue concerning the design of FEE-HELP is that the loan is capped at a total level of $\$ 50,000$ per student. This is likely to result in the 
emergence of up-front fees for some students to allow them to complete their courses. If this happens our exercises show quite powerfully that such a scenario will add very significantly to the relative charge obligations of those graduates earning the least over their lifetimes.

One final comment on both FEE-HELP and HECS-HELP is the implications of the new arrangements for the access of students from different socio-economic backgrounds. This is a very important issue but one that this exercise is unable to offer insights into. Further research could shed some light on this matter.

\section{Conclusion}

In the current funding environment many universities are considering whether an increase in the HECS charge is a desirable policy option and if so, how great the increase should be. In this study we have examined the effects of increasing the HECS charge by 25 per cent for HECS-HELP students, introducing debts of $\$ 50,000$ for FEE-HELP students and having up-front fees on top of a $\$ 50,000$ FEE-HELP debt.

One important question is the likely impact upon students and graduates of such changes. The appropriate way to assess this is through examination of the present value of the repayments made by graduates differing in future incomes faced. These parameters are critical to an assessment of the possible impact of HECS-HELP, since once the debt is incurred there is a real interest rate of zero, implying the possibility of very large differences between individuals in the present value of changes to HECS.

The first part of this study has explored these issues for HECS-HELP graduates under a system of a 25 per cent HECS surcharge and applying the 2005-06 HECS repayment schedule. Analysis was undertaken of three types of hypothetical graduates - males, females without children and females with two children. Each of these graduates was assigned three different income levels (high, medium and low). Results were reported for the middle HECS band results for the other HECS bands are similar.

The analysis demonstrates that the lifetime profiles of graduates vary greatly and thus so too will the impact of changes to the HECS system. For example, even increasing the HECS charge by 25 per cent results in substantial falls in the financial burden of a HECS debt for low-income males and, especially, lowincome female graduates, compared with the current system. This is due to the very large increase in the first income threshold of repayment of HECS, which effectively delivers substantial HECS reductions for many individuals.

For 'average' males and females (those earning middle incomes), an increase of 25 per cent in the HECS charge will result in a slightly lower true financial cost than this (around 18 per cent for 'average' males and females without children). On the other hand, people with high incomes will in effect pay about 25 per cent more.

The second part of this study examined the impact of changes to the HECS system on FEE-HELP students. Two broad scenarios were explored: a debt of 
$\$ 12,500$ per year for the four years of tertiary education; and a debt of $\$ 50,000$ in combination with a likely typical up-front fee (chosen to reflect the impact of the capping of the loan).

The analysis shows that incurring a total debt of $\$ 50,000$ results in substantial increases in the present values of the debt for middle and high-income graduates. However, for low-income individuals, especially low-income women with children, the present value of HECS repayments is nowhere near as great as for their higher income counterparts, because none of the low-income individuals in this study will fully repay their debt. In the case of low-income women with children, repayments are even less (relative to their counterparts without children) because they spend a substantial amount of time out of the labour force and working part time.

However, if the capping of the loan leads to up-front fees, the effects are much more considerable and arguably much more regressive. It was found, for example, that the up-front component of this policy variant would result in a very considerable increase in the present value of charges for female graduates receiving low future incomes, of the order of 3 and 8 fold. Accordingly, and different to the likely effects of HECS-HELP, this aspect of FEE-HELP has the important potential to jeopardise the access of those who expect to receive relatively low future incomes. While this does not necessarily mean that relatively poor students at the point of entry will be adversely affected, this aspect of the 2005 reforms seems to be very regressive when viewed in a lifetime context.

\section{References}

Andrews, L. (1999), 'Does HECS Deter?’, Department of Education, Training and Youth Affairs, Occasional Paper Number 99F, Canberra.

Chapman, B. (1997), 'Conceptual Issues and the Australian Experience with Income Contingent Charges for Higher Education’, The Economic Journal 107(442):738-751.

Chapman, B. and T. Salvage (2001), 'Post-graduate Charge Policy’, Agenda 8(4):349-364.

Chapman, B. and C. Ryan (2002), 'Income Contingent Financing of Student Higher Education Charges: Assessing the Australian Innovation', The Welsh Journal of Education 11(1):64-81.

Edwards, M., C. Howard and R. Miller (2001), Social Policy, Public Policy: From Problem to Practice, Allen and Unwin, Sydney.

Friedman, M. (1955), 'The Role of Government in Education', pp 123-44 in A. Solo (ed.), Economics and the Public Interest, Rutgers University Press, New Brunswick, NJ.

Phillips, D. and B. Chapman (2003), ‘Our Universities: Backing Australia's Future. Issues and Analysis’, mimeo, Australian National University, Canberra, July. 
174 Gillian Beer and Bruce Chapman

The authors wish to acknowledge the valuable input from the editor and two anonymous referees. We also wish to acknowledge the support of the University of Sydney, the University of Western Australia, La Trobe University and RMIT University. All errors and omissions are those of the authors alone. 